\title{
Predicting parameters of degradation succession processes of Tibetan Kobresia grasslands
}

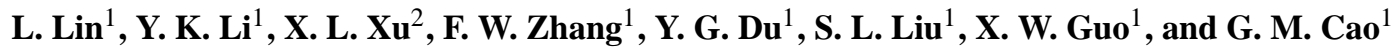 \\ ${ }^{1}$ Northwest Institute of Plateau Biology, Chinese Academy of Sciences, Xining 810001, China \\ ${ }^{2}$ Key Laboratory of Ecosystem Network Observation and Modeling, Institute of Geographic Sciences and Natural Resources, \\ Chinese Academy of Sciences, Beijing 100101, China
}

Correspondence to: Y. K. Li (liyikang501@163.com) and X. L. Xu (xuxingl@ hotmail.com)

Received: 1 June 2015 - Published in Solid Earth Discuss.: 6 August 2015

Revised: 23 October 2015 - Accepted: 26 October 2015 - Published: 20 November 2015

\begin{abstract}
In the past two decades, increasing human activity (i.e., overgrazing) in the Tibetan Plateau has strongly influenced plant succession processes, resulting in the degradation of alpine grasslands. Therefore, it is necessary to diagnose the degree of degradation to enable implementation of appropriate management for sustainable exploitation and protection of alpine grasslands. Here, we investigated environmental factors and plant functional group (PFG) quantity factors during the alpine grassland succession processes. Principal component analysis (PCA) was used to identify the parameters indicative of degradation. We divided the entire degradation process into six stages. PFG types shifted from rhizome bunchgrasses to rhizome plexus and denseplexus grasses during the degradation process. Leguminosae and Gramineae plants were replaced by sedges during the advanced stages of degradation. The PFGs were classified into two reaction groups: the grazing-sensitive group, containing Kobresia humilis Mey, and Gramineae and Leguminosae plants, and the grazing-insensitive group, containing Kobresia pygmaea Clarke. The first group was correlated with live root biomass in the surface soil $(0-10 \mathrm{~cm})$, whereas the second group was strongly correlated with mattic epipedon thickness and $K$. pygmaea characteristics. The degree of degradation of alpine meadows may be delineated by development of mattic epipedon and PFG composition. Thus, meadows could be easily graded and their use adjusted based on our scaling system, which would help prevent irreversible degradation of important grasslands. Because relatively few environmental factors are investigated, this approach can save time and labor to formulate a conservation management plan for degraded alpine meadows.
\end{abstract}

\section{Introduction}

Alpine grasslands are one of the most important grassland types on earth, and they are distributed across the tundra zone of northern Eurasia and North America. More than $48 \%$ of alpine grasslands are distributed on the Tibetan Plateau of China (Sun and Zheng, 1998; Wang et al., 1998; Harmsen et al., 2008). Alpine grasslands represent one of the major natural types of pastures for pastoralists living in alpine regions, especially for those living on the Tibetan Plateau, where livestock grazing is the most important human activity (Zhang et al., 2003).

Livestock mainly affects alpine grasslands through two ways. First, their grazing can affect the structure and composition of plant community, and the constitution of plant life forms and ecotypes in alpine grasslands (de la Paix et al., 2013; Zhao et al., 2013; Mekuria and Aynekulu, 2013). Second, their trampling can reduce infiltration rates, surface sealing, and physical crust formation (Cerdà and Lavee, 1999; Angassa, 2014). With increased grazing, a part of alpine grasslands gradually degrade and become bare soil due to decreased vegetation protection (Zhang et al., 2003a, b; G. X. Wang et al., 2007, Q. L. Wang et al., 2007; Foggin, 2008). Consequently, this reduces the role of alpine grasslands in soil and water protection (Wen et al., 2010; Brandt et al., 2013; You et al., 2014). Such grazing-induced degradation of alpine grasslands was observed in the early $2000 \mathrm{~s}$ (Q. L. Wang et al., 1997; Liu et al., 2008; Wang et al., 2009; Harris, 2010; Lin et al., 2013a, b), mainly because livestock number increased from approximately $0.8 \times 10^{8}$ in 1997 to $1.08 \times 10^{8}$ sheep units in 2011 on the Tibetan Plateau (Yang, 2002; He et al., 2008; Sun, 2012). 
In the past decade, degradation in alpine grasslands has been getting more and more serious due to increasing grazing density. This has started to affect the living of pastoralists and the development of local economy. How to restore these degraded grasslands and maintain sustainable development of alpine grasslands is a big challenge. An important prerequisite for this is how to diagnose the degree to which alpine grasslands have degraded ( $\mathrm{Li}$ et al., 2014). So far, numerous studies have separately used plant community (Han et al., 2008; Lin et al., 2013a, b; Angassa, 2014; Giangiacomo, 2014) or environmental indexes (Lin et al., 2010, 2013a, b) as indicators to diagnose grassland degradation (Li et al., 2014; Wang et al., 2015). However, grassland degradation caused by grazing is a very complicated ecological process, including changes in both vegetation and soil. This emphasizes the importance of the plant-soil system for improving degradation of alpine grasslands.

Among the plant-soil system, plants are the link of the atmosphere, biosphere, hydrosphere, and lithosphere (Brevik et al., 2015). The existence of plants can protect the soil surface against kinetic energy of drops, reduces runoff, and increases infiltration (Groen and Woods, 2008). Therefore, the vegetation cover plays a fundamental role in the soil development and soil erosion (Cerdà, 2002; Keesstra et al., 2014), and soil degradation (Ziadat and Taimeh, 2013), and also in the geomorphological (Nanko et al., 2015) and hydrological behavior of the Earth system (Keesstra, 2007; GabarrónGaleote et al., 2013) and their interactions with the biota (Araújo et al., 2014; Bochet et al., 2015). At the same time, plants can shape soil microenvironments through living roots (Bardgett, 2002; Puente et al., 2004; Cerdà, 2002; Dai et al., 2013; Keesstra et al., 2014; Shang et al., 2014; Keesstra, 2014; Gabarrón-Galeote et al., 2013) and affect microbial function (Wang et al., 2015; Pereg and McMillan, 2015). In contrast to vegetation, the soil system provides an important carrier for growth of plants and microorganisms. Almost all nutrient transformation processes operate by microorganisms in the soil. Therefore, the analysis on the soil-plant system must be approached from a multidisciplinary strategy (Brevik et al., 2015).

To identify the degradation stages of the Tibetan Kobresia grasslands, we conducted a large field investigation in alpine grasslands across the Qinghai province. We collected a large number of indicators, including visible (e.g., species diversity, plant height, vegetation coverage, and plant biomass, plant functional groups) and invisible (e.g., root biomass, organic matter content, total nitrogen, and available nutrients in the soil). To reduce the parameters dimensionality (Lin et al., 2012a), ordination and classification approaches were used for the multivariate analysis because it has been used to explore which factors contribute most to plant community change (Ali et al., 2014; Christopher et al., 2014). Therefore, our objectives of this study are to (1) analyze the degree of degradation in grasslands through reducing the parameter dimensionality from a large number of visible and invisible pa- rameters and (2) develop a useful approach to diagnose and predict the extent of degradation of alpine grasslands for the sustainable development of alpine grasslands.

\section{Materials and methods}

\subsection{Study area}

The experimental sites were located in the flat ground whose slopes are less than $5^{\circ}$. And the experimental sites were distributed in districts of Haibei, Guoluo, and Yushu in Qinghai province, China. These sites are characterized by a typical alpine climate and are dominated by typical alpine grasslands. Detailed information on these sites is presented in Fig. 1 .

In this study, we investigated 96 plots $(100 \mathrm{~m} \times 100 \mathrm{~m})$ from 32 counties in three districts. These plots were selected according to the following criteria: similar annual average precipitation $(509.2 \pm 23.7 \mathrm{~mm})$ and temperature $\left(-1.04 \pm 0.4^{\circ} \mathrm{C}\right)$, along with the same grassland type (alpine Kobresia meadow) over the past two decades. This was achieved according to the grassland resource map of China at the 1:1000000 scale (1992). Different changes in these grasslands from 1992 to 2012 were largely due to degradation in the past two decades. On the basis of the change in plant communities, we divided the 96 plots into 6 vegetation types and chose 2-3 plots in every type to study the plant community and soil properties (Fig. 1, Table 1, Lin et al., 2012b): (1) Gramineae grass-Kobresia humilis Mey community (stage I), (2) K. humilis community (stage II), (3) thickening in mattic epipedon of the Kobresia pygmaea Clarke community (stage III), (4) cracks in mattic epipedon of the K. pygmaea community (stage IV), (5) collapse in mattic epipedon of the K. pygmaea community (stage V), and (6) forbs-"black-soil beach" (stage VI). Detailed information about the vegetation types of typical experimental sites is presented in Table 1.

\subsection{Field investigations and laboratory analyses}

Total vegetation coverage, the percentage coverage of each plant functional group, and the aboveground/belowground biomass proportion in all plots were investigated in August 2009. Aboveground biomass was estimated by harvesting plants from five $0.25 \mathrm{~m}^{2}$ quadrats selected randomly within each plot.

Gramineae and sedge are divided into three major plant life forms (PLFs) in Tibetan Kobresia meadows. All the three PLFs are edible but have different traits. One is a rhizome bunch type. This type propagates by rhizomes and seeds. In general, this type germinates in early spring, and the seeds mature in early autumn. This PLF is highly sensitive to grazing because the period of grazing by animals and high growth sensitivity of the plants coincide. The second PLF is the rhizome plexus type. This type propagates mainly through its rhizomes. They often dominate the lower layer $(3-5 \mathrm{~cm})$ of 


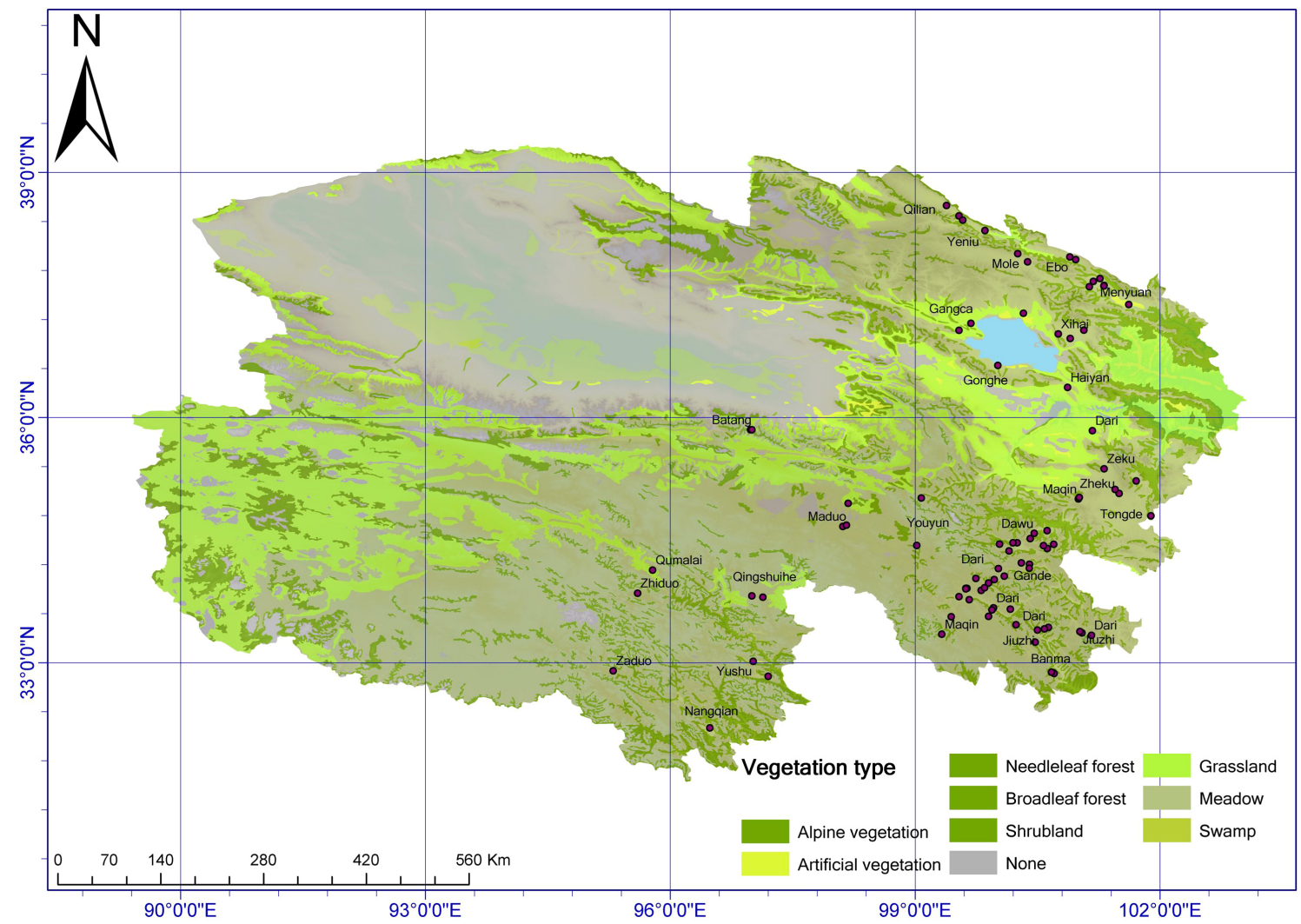

Figure 1. The locations of experimental sites.

the plant community. The third PLF is the rhizome denseplexus type. Due to the dense plexus, this type is able to accelerate the development of the mattic epipedon. The soil surface of alpine meadows contains a mixture of live and dead roots of different ages, which is called mattic epipedon. It is an active layer where nutrients and energy exchange occur very quickly. As a result, excess root growth causes an imbalance between soil nutrients and soil moisture, which accelerates the degradation of alpine grasslands. K. pygmaea is a typical species that contributes to this process.

On the basis of the stated traits, plants were divided into six plant functional groups (PFGs): Gramineae, other sedges, $K$. humilis, K. pygmaea, Leguminosae, and forbs (Table 2). Roots were collected from two soil depths (0-10 and 10$20 \mathrm{~cm})$ with an earth auger $(6 \mathrm{~cm}$ diameter). In each plot, 25 cores were randomly collected, with every 5 cores being pooled together as a combined sample. In each plot, there were five combined samples. The cutting ring method was used to estimate bulk density in the top $10 \mathrm{~cm}$ of soil. Large root fragments were washed after the associated soil was passed through a $0.25 \mathrm{~mm}$ sieve. The proportion method was used to distinguish live from dead roots (Lu et al., 2007). All plant materials were dried in an oven at $80^{\circ} \mathrm{C}$ for $48 \mathrm{~h}$ and weighed for biomass determination (Chinese Ecosystem Research Network Scientific Committee, 2007). Plant commu- nity importance values included estimates of the average of relative coverage and relative aboveground biomass of PFGs.

\subsection{Statistical analysis}

All statistical analyses and construction of graphs were performed by the Canoco 4.5 software package for Windows. Euclidean cluster analysis (ECA) was used to divide the 96 plots into 6 stages. Live root biomass, dead root biomass, soil bulk density, and the thickness of mattic epipedon were used as the environmental factors in the principal component analysis (PCA). Pearson's correlation coefficient was calculated to identify any correlations between variables. Arithmetic means with standard errors were calculated for all of the data. Plant community importance values were based on the follow equation:

$\mathrm{IV}=\frac{C+B}{2}$,

where "IV" represents "important value", " $C$ " represents "average of the relative coverage", and " $B$ " represents "relative aboveground biomass". Values are considered significant at the $P<0.05$ level. 

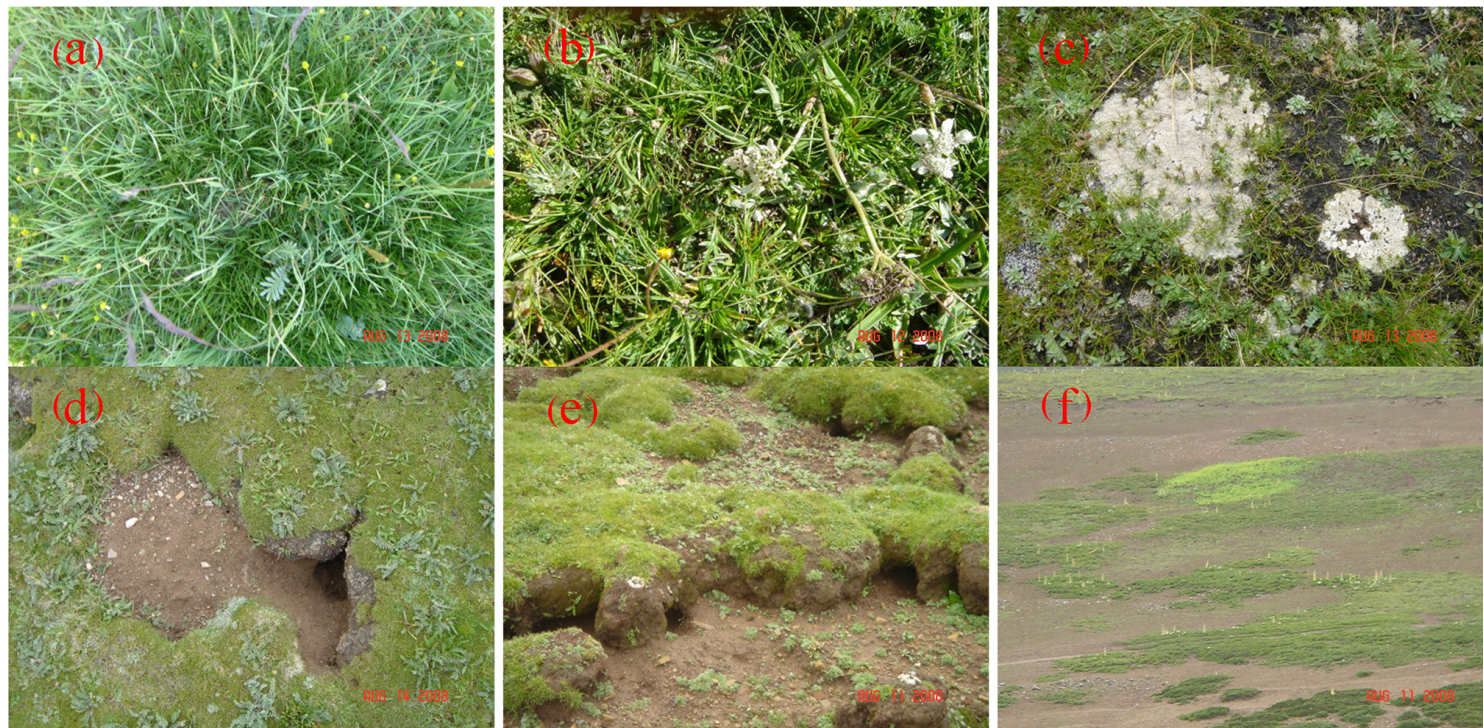

Figure 2. The degradation succession of Tibetan alpine Kobresia grasslands was divided into six stages: (a) the Gramineae grass-K. humilis community (stage I), (b) the K. humilis community (stage II), (c) the thickening in mattic epipedon of the K. pygmaea community (stage III), (d) the cracks in mattic epipedon of the K. pygmaea community (stage IV), (e) the collapse in mattic epipedon of the K. pygmaea community (stage V), and (f) the forbs-black-soil beach (stage VI).

Table 1. Detailed information about the six degradation successional stages of alpine Kobresia grasslands.

\begin{tabular}{|c|c|c|c|c|c|}
\hline Succession stage & Abbreviation & & Study area & Geographical position & Plot general situation \\
\hline $\begin{array}{l}\text { Gramineae grass }-K \text {. } \\
\text { humilis community }\end{array}$ & $\mathrm{HC}$ & Stage I & $\begin{array}{l}\text { Maqin County } \\
\text { of Guoluo } \\
\text { Huangcheng County } \\
\text { of Haibei } \\
\text { Ebo County } \\
\text { of Haibei }\end{array}$ & $\begin{array}{l}34^{\circ} 28^{\prime} \mathrm{N}, 100^{\circ} 12^{\prime} \mathrm{E} \\
3751 \mathrm{ma} \text { a.s. } 1 . \\
37^{\circ} 40^{\prime} \mathrm{N}, 101^{\circ} 11^{\prime} \mathrm{E} \\
3232 \mathrm{ma} \text { a.s. } 1 . \\
37^{\circ} 56^{\prime} \mathrm{N}, 100^{\circ} 58^{\prime} \mathrm{E} \\
3419 \text { ma.s.l. }\end{array}$ & $\begin{array}{l}\text { Dominant plants are Elymus nutans, Poa sp., Fes- } \\
\text { tuca rubra, coverage } 93 \% \text {, the thickness of the mat- } \\
\text { tic epipedon is } 1.66 \mathrm{~cm} \text {, the average livestock num- } \\
\text { ber is } 4 \text { sheep units ha }{ }^{-1}\end{array}$ \\
\hline $\begin{array}{l}\text { K. humilis } \\
\text { community }\end{array}$ & AS & Stage II & $\begin{array}{l}\text { Huangcheng County } \\
\text { of Haibei } \\
\text { Batang County } \\
\text { of Yushu }\end{array}$ & $\begin{array}{l}37^{\circ} 40^{\prime} \mathrm{N}, 101^{\circ} 11^{\prime} \mathrm{E} \\
3232 \mathrm{~m} \text { a.s. } 1 . \\
35^{\circ} 51^{\prime} \mathrm{N}, 96^{\circ} 60^{\prime} \mathrm{E} \\
3907 \text { ma.s. } 1 .\end{array}$ & $\begin{array}{l}\text { Dominant plants are } K . \text { humilis, subdominant } \\
\text { species are } E \text {. nutans, Poa sp. and } F \text {. rubra, cov- } \\
\text { erage } 96.7 \% \text {, the average thickness of the mattic } \\
\text { epipedon is more than } 2 \mathrm{~cm} \text { but less than } 3 \mathrm{~cm} \text {, the } \\
\text { average livestock number is } 8 \text { sheep units ha }{ }^{-1} \text {. }\end{array}$ \\
\hline $\begin{array}{l}\text { Thickening in mattic } \\
\text { epipedon } \\
\text { K. pygmaea } \\
\text { community }\end{array}$ & XS1 & Stage III & $\begin{array}{l}\text { Maqin County } \\
\text { of Guoluo } \\
\text { Huangcheng County } \\
\text { of Haibei }\end{array}$ & $\begin{array}{l}34^{\circ} 28^{\prime} \mathrm{N}, 100^{\circ} 12^{\prime} \mathrm{E} \\
3751 \mathrm{~m} \text { a.s. } 1 . \\
37^{\circ} 40^{\prime} \mathrm{N}, 101^{\circ} 11^{\prime} \mathrm{E} \\
3232 \mathrm{~m} \text { a.s. } 1 .\end{array}$ & $\begin{array}{l}\text { Dominant plants are } K . \text { pygmaea, coverage } 81 \% \text {, } \\
\text { the meadow has a rugged surface, the average thick- } \\
\text { ness of the mattic epipedon is more than } 3 \mathrm{~cm} \text { but } \\
\text { less than } 5 \mathrm{~cm} \text {, the average livestock number is } 11 \\
\text { sheep units ha }\end{array}$ \\
\hline $\begin{array}{l}\text { Cracks in mattic } \\
\text { epipedon } \\
\text { K. pygmaea } \\
\text { community }\end{array}$ & XS2 & Stage IV & $\begin{array}{l}\text { Maqin County } \\
\text { of Guoluo } \\
\text { Batang River } \\
\text { beaches of Yushu }\end{array}$ & $\begin{array}{l}37^{\circ} 40^{\prime} \mathrm{N}, 101^{\circ} 11^{\prime} \mathrm{E} \\
3232 \mathrm{ma} . \mathrm{s} .1 . \\
35^{\circ} 51^{\prime} \mathrm{N}, 96^{\circ} 60^{\prime} \mathrm{E} \\
3907 \text { ma.s. } 1 .\end{array}$ & $\begin{array}{l}\text { Dominant plant is } K \text {. pygmaea, the alpine } K . \text { pyg- } \\
\text { maea species mottling are not less than } 85 \% \text {; there } \\
\text { are many crannies dividing the meadow into big } \\
\text { alpine } K \text {. pygmaea mottling, there is hypogenesis of } \\
K \text {. pygmaea within the mottling, the average thick- } \\
\text { ness of the mattic epipedon is more than } 5 \mathrm{~cm} \text { but } \\
\text { less than } 7 \mathrm{~cm} \text {, the average livestock number is } 13 \\
\text { sheep units ha }\end{array}$ \\
\hline $\begin{array}{l}\text { Collapse in mattic } \\
\text { epipedon } \\
\text { K. pygmaea } \\
\text { community }\end{array}$ & XS3 & Stage V & $\begin{array}{l}\text { Maqin County } \\
\text { of Guoluo } \\
\text { Huangcheng County } \\
\text { of Haibei } \\
\text { Ebo County } \\
\text { of Haibei }\end{array}$ & $\begin{array}{l}34^{\circ} 28^{\prime} \mathrm{N}, 100^{\circ} 12^{\prime} \mathrm{E} \\
3751 \mathrm{~m} \text { a.s. } 1 . \\
37^{\circ} 40^{\prime} \mathrm{N}, 101^{\circ} 11^{\prime} \mathrm{E} \\
3232 \mathrm{~m} \text { a.s. } 1 . \\
37^{\circ} 56^{\prime} \mathrm{N}, 100^{\circ} 58^{\prime} \mathrm{E}\end{array}$ & $\begin{array}{l}\text { Dominant plant is } K \text {. pygmaea, the meadow surface } \\
\text { is intensity collapsed into a lot of insulation mattic } \\
\text { epipedon islands, the collapse ground is parent ma- } \\
\text { terial, the average thickness of the mattic epipedon } \\
\text { is more than } 7 \mathrm{~cm} \text {, the average livestock number is } \\
14 \text { sheep units ha }{ }^{-1}\end{array}$ \\
\hline Forbs-black-soil beach & $\mathrm{HZ}$ & Stage VI & $\begin{array}{l}\text { Maqin County } \\
\text { of Guoluo } \\
\text { Menyuan County } \\
\text { of Haibei }\end{array}$ & $\begin{array}{l}34^{\circ} 28^{\prime} \mathrm{N}, 100^{\circ} 12^{\prime} \mathrm{E} \\
3751 \mathrm{~m} \text { a.s. } 1 . \\
37^{\circ} 37^{\prime} \mathrm{N}, 101^{\circ} 19^{\prime} \mathrm{E} \\
3196 \text { m a.s. } 1 .\end{array}$ & $\begin{array}{l}\text { The dominant plants are forbs, with } K \text {. pygmaea, } \\
\text { coverage is } 46 \% \text {, there is no mattic epipedon, the } \\
\text { surface is loose, in winters there are no plants cov- } \\
\text { ering the ground, there is no edible plant for grazing }\end{array}$ \\
\hline
\end{tabular}


Table 2. Plant functional groups and their composition or traits.

\begin{tabular}{ll}
\hline Plant functional group & Main composition and/or traits \\
\hline Gramineae & Composition: Festuca spp., Stipa spp., Poa spp., etc. \\
& Trait: rhizome bunch type, rhizome plexus type, and rhi- \\
& zome dense-plexus type. \\
K. humilis & Trait: rhizome plexus type. \\
K. pygmaea & Trait: rhizome dense-plexus type. \\
Other sedges & Composition: Carex spp., Cyperus spp., Kobresia spp. \\
& (exclusively K. humilis and K. pygmaea), etc. \\
& Trait: rhizome bunch type, rhizome plexus type and rhi- \\
& zome dense-plexus type. \\
& Composition: Gueldenstaedtia verna, Melissilus \\
Leguminosae & ruthenicus, Oxytropis spp., Astragalus spp., etc. \\
& Trait: axis root plants. \\
& Composition: Asteraceae, Gentianaceae, etc. \\
Forbs & Trait: non-leguminous broad-leaved herbs. \\
&
\end{tabular}

\section{Results}

\subsection{PFG characteristics}

The succession process of the alpine Kobresia grassland involved the replacement of plant functional groups (Fig. 2). Gramineae was the dominant edible forage type, and had the highest husbandry value of all forage matter during community succession. The highest importance value was $40.7 \pm 1.8 \%$ presented in stage I: it was significantly higher than at stages IV, V, and VI, and had no difference between stage II and III. The lowest one was $9.5 \pm 2.3 \%$ presented in stage IV, and it was significantly lower than stage I, II, III, and V, but had no significant difference to stage VI (Fig. 3a). The important values of Gramineae ranged from $28.6 \pm 2.1$ to $40.8 \pm 1.8 \%$. The highest values were recorded in stage III, and there was no significant difference between the first three stages. $K$. humilis belongs to the Cyperaceae family and was widely distributed among the dwarf plants during the entire growing season. By comparison, K. humilis disappeared from stage $\mathrm{V}$ onwards (Fig. 3b). During the succession process, $K$. pygmaea gradually replaced Gramineae. The contribution of $K$. pygmaea was minimal during the first three stages of succession, but increased from stage IV onwards. The highest importance value $(48.7 \pm 3.9 \%)$ of $K$. pygmaea appeared in stage V (Fig. 3c).

As the grassland became increasingly degraded, the importance values of Leguminosae initially increased and then decreased (Fig. 3e). The importance values of Forbs were low during stages I and VI, but were similarly high during all other stages (Fig. 3a-f).

\subsection{Root biomass and distribution}

The quantity of both live and dead roots increased during early succession, and then decreased with increasing grassland degradation. The highest live-root biomass in the top $10 \mathrm{~cm}$ of soil occurred at stage IV $\left(19.4 \pm 1.8 \mathrm{~kg} \mathrm{~m}^{-2}\right)$, while the highest dead-root biomass occurred at stage $\mathrm{V}$ $\left(29.3 \pm 2.31 \mathrm{~kg} \mathrm{~m}^{-2}\right)$. Dead-root biomass was consistently higher than live-root biomass in the top $10 \mathrm{~cm}$ soil (Fig. 4a).

Live- and dead-root biomass in the $10-20 \mathrm{~cm}$ soil layer increased during the early stages of succession, with a steep decrease in the final stage (Fig. 4). Similar live-root biomass was recorded between stages II and III, but was significantly higher at stage IV compared to stages I and VI. The highest dead-root biomass was recorded at stage $\mathrm{V}$ (Fig. $4 \mathrm{~b}$ ).

\subsection{Thickness of the mattic epipedon and soil bulk density}

The thickness of the mattic epipedon increased over the first five stages of succession; however, the mattic epipedon disappeared at the final stage, because it was destroyed. The greatest thickness of the mattic epipedon occurred at stage $\mathrm{V}$ $(18.4 \pm 0.8 \mathrm{~cm})$. In comparison, stage IV represented a transition stage, before which the thickness was approximately $5 \mathrm{~cm}$ (Fig. 5).

Soil bulk density in the top $10 \mathrm{~cm}$ decreased with the succession process, due to increased root biomass, with the lowest value being recorded at stage IV, and then increased in the final stage, with the highest value of $1.1 \pm 0.1 \mathrm{~g} \mathrm{~cm}^{-3}$ (Fig. 6).

\subsection{Bare-ground coverage in the plant community}

Bare-ground coverage in the plant community increased during community succession, showing three states. The first state was in stage I, in which almost all soil was covered (93\% coverage). The second state included stages II and III, with approximately $20 \%$ bare-ground coverage. The third state encompassed stages IV to VI, with approximately $50 \%$ space coverage (Fig. 7). 


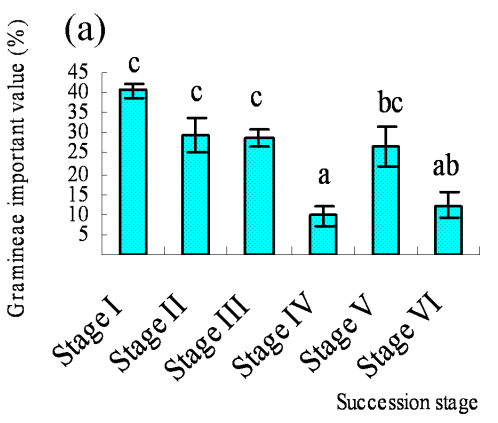

(d)

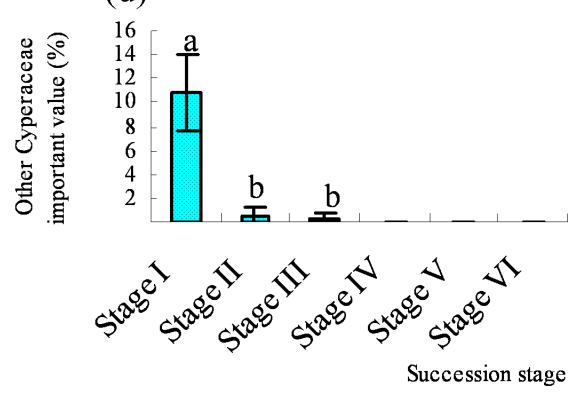

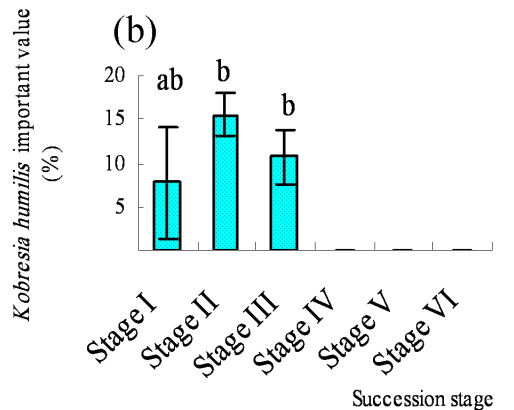

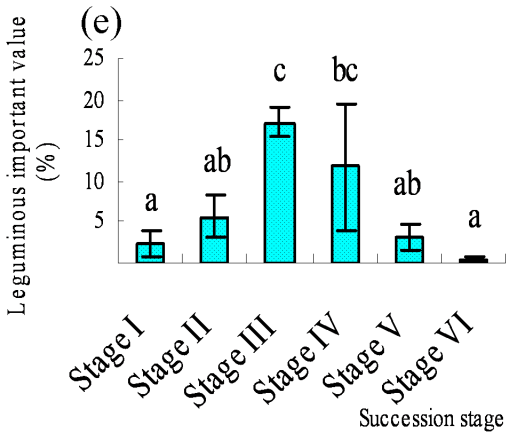

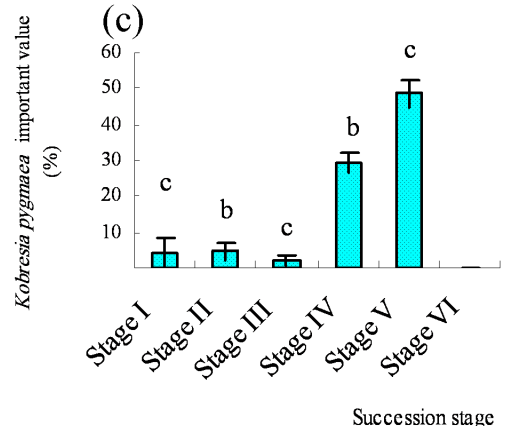

(f)

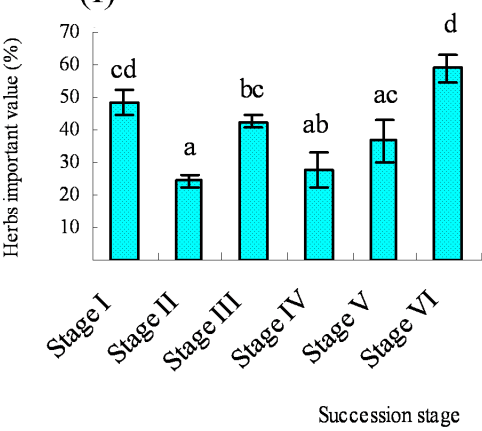

Figure 3. The characteristics of the four plant functional groups in a degradation successional series of Tibetan alpine grasslands: (a) Gramineae, (b) Kobresia humilis, (c) Kobresia pygmaea, (d) other sedges, (e) Leguminosae, and (f) Forbs. Different letters in the figures indicate significant differences between the stages at $P<0.05$.
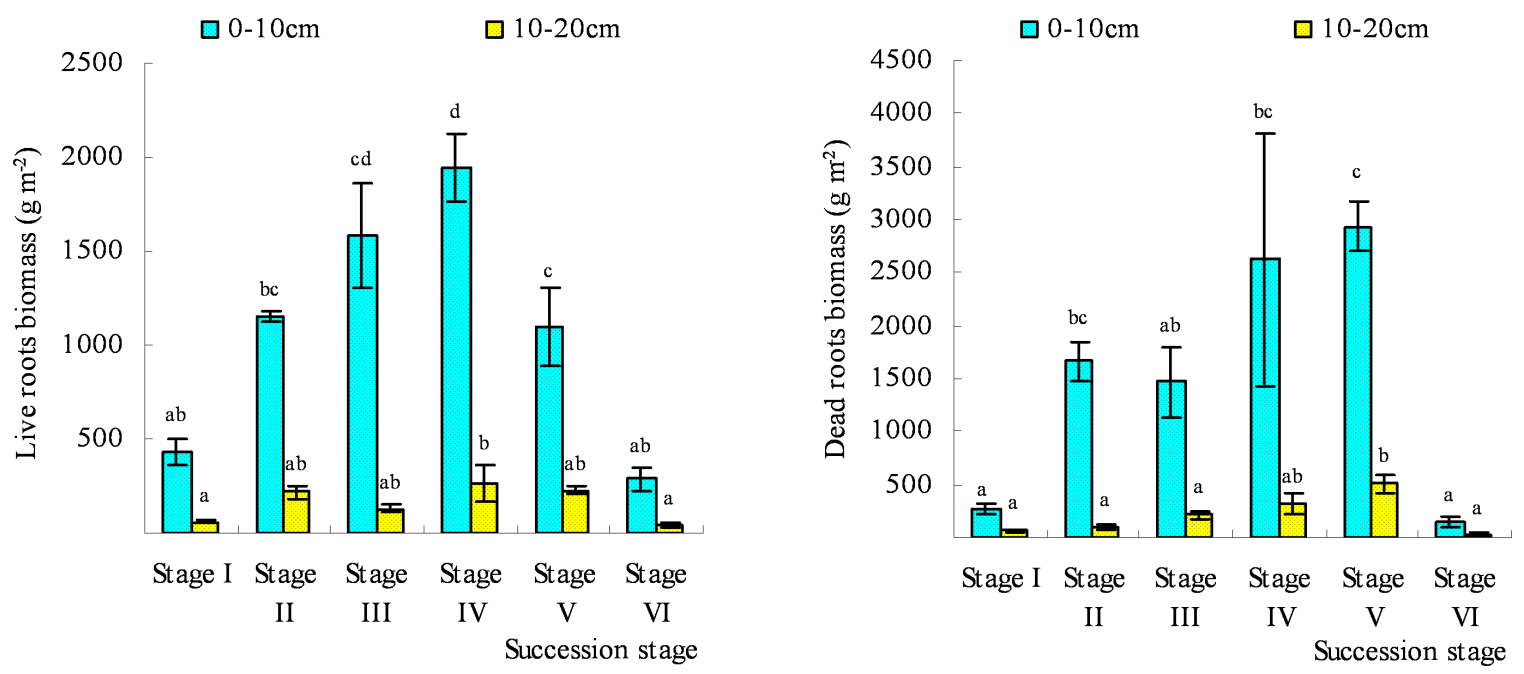

Figure 4. Living-root biomass (left) and dead-root biomass (right) at $0-10$ and $10-20 \mathrm{~cm}$ depths. The values represent the means \pm 1 SD of four replicates. Different letters in the figures indicate significant differences between the stages at $P<0.05$. The stage details refer to Fig. 2 .

\subsection{Relationship between PFGs and the environment}

The principal component analysis of the PFG and environmental factors matrices showed that two important principal components explained $82.9 \%$ of the total variance (Fig. 8). The first axis explained $49.1 \%$ of the total variance, showing a strong positive correlation with $K$. pygmaea and a negative correlation with Leguminosae and Gramineae. The first principle axis also showed a positive correlation with the thickness and area of the mattic epipedon and a negative correlation with live-root biomass. The second principle axis explained $33.8 \%$ of total variance, showing a positive correlation with forbs and a negative correlation with Leguminosae, Gramineae, and K. pygmaea. The second axis was positively 


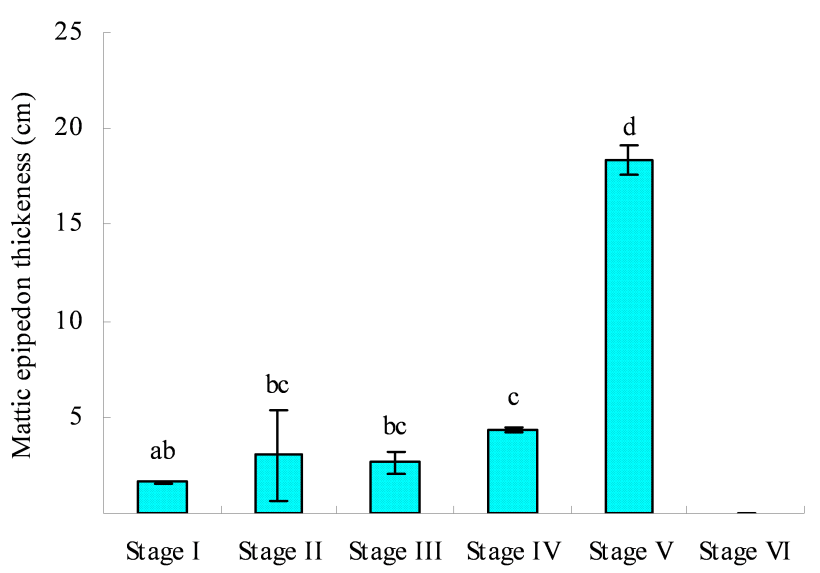

Succession stage

Figure 5. The thickness of mattic epipedon over the course of succession. The values represent the means \pm 1 SD of four replicates. Different letters in the figures indicate significant differences between stages at $P<0.05$. The stage details refer to Fig. 2 .

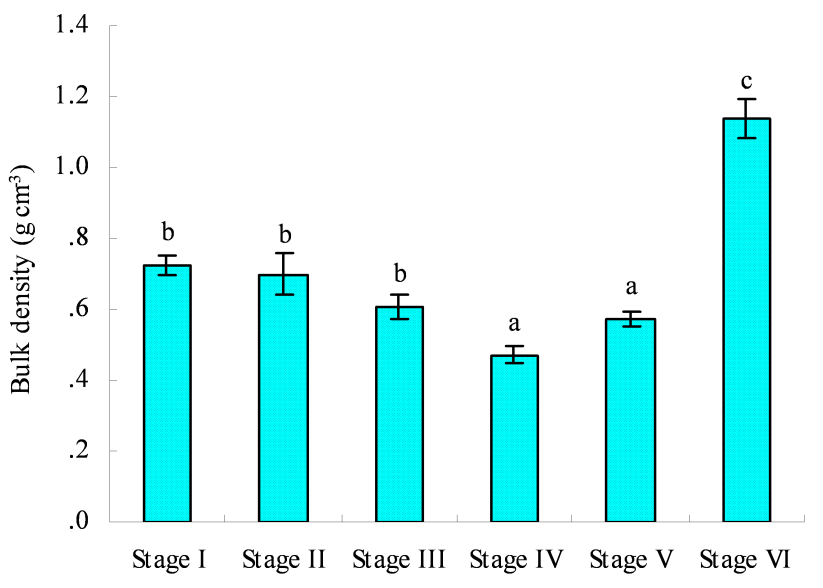

Succession stage

Figure 6. Surface soil-bulk density over the course of succession. The values represent the means $\pm 1 \mathrm{SD}$ of four replicates. Different letters in the figures indicate significant differences between stages at $P<0.05$. The stage details refer to Fig. 2 .

correlated with soil bulk weight and negatively correlated with live- and dead-root biomass (Fig. 8).

The environmental factors were divided into two new types: (1) the first environmental axis was related to mattic epipedon characteristics, whereas (2) the second environmental axis was related to soil bulk weight. The first PFG was strongly related with the plexus-type plant group. The second plant functional group was strongly related with the foragetype plant group (Fig. 8). The thickness of mattic epipedon had a strong positive correlation with $K$. pygmaea. Soil bulk density had a strong positive correlation with herbs but a negative correlation with Gramineae and Leguminosae.

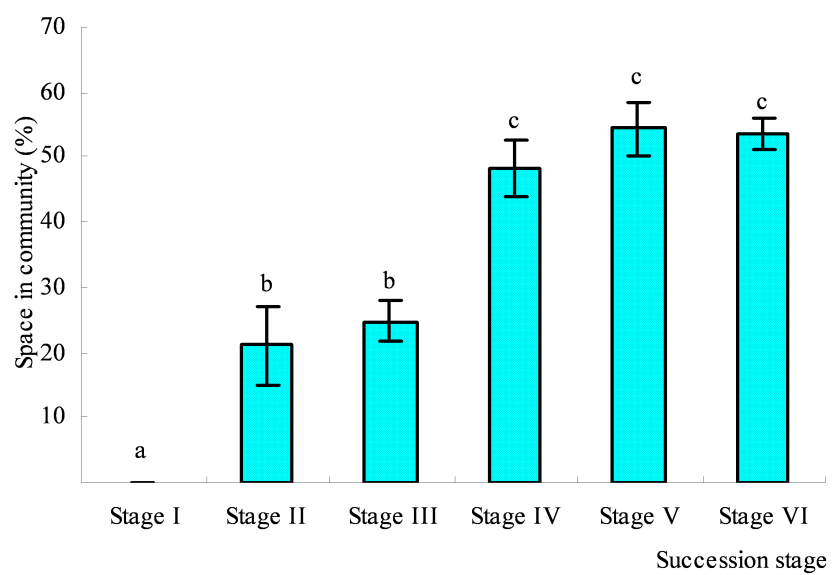

Figure 7. The space coverage over the course of succession. The values represent the means \pm 1 SD of four replicates. Different letters in the figures indicate significant differences between stages at $P<0.05$. The stage details refer to Fig. 2 .

\section{Discussion}

As Kobresia grasslands became degraded, there was a clear shift in dominant PFGs. This shift has been previously linked to trampling and selective grazing by livestock (Cao et al., 2007; Du et al., 2007; J. Y. Lin et al., 2012; Lin, 2013a, b), and the shift was Leguminosae and Gramineae plants were replaced by sedges when the livestock grazing intensity increased. In alpine grasslands, Stipa spp. and Festuca spp. are highly edible Gramineae forage (Wang et al., 2008). These plants turn green in early spring and continue to have high aboveground biomass in autumn when the plant community withers. Overgrazing at the turning-green period (i.e., early spring) and the fructification period in autumn interrupts the normal growing cycle of these plants and reduces their dominance in the plant community. Consequently, the dominance of low feeding-value plants (e.g., non-leguminous broadleaved herbs) or low-growing plants (e.g., K. pygmaea and $K$. humilis) increases (L. Lin et al., 2012). Therefore, PFGs are expected to reflect the effects of grazing on alpine grasslands and the degradation process.

A clear changing pattern in PFG characteristics and environmental factors during the degradation process (Fig. 8) is mainly caused by a shift from sensitive to endurable plants in response to grazing pressure. As livestock number increases in alpine grasslands, dense-plexus plants (K. pygmaea) replace rhizome plexus-type plants (e.g., Scirpus spp. and $K$. humilis) as the dominant vegetation type in the community. K. pygmaea differing from other sedges, such as Scirpus spp. and $K$. humilis, may help to maintain the community structure despite substantial livestock grazing (Lin et al., 2008; Wang et al., 2008), because it increases root biomass, which safeguards plants against livestock pressure and increases the activity of the plant community. This response causes the thickness of the mattic epipedon to in- 

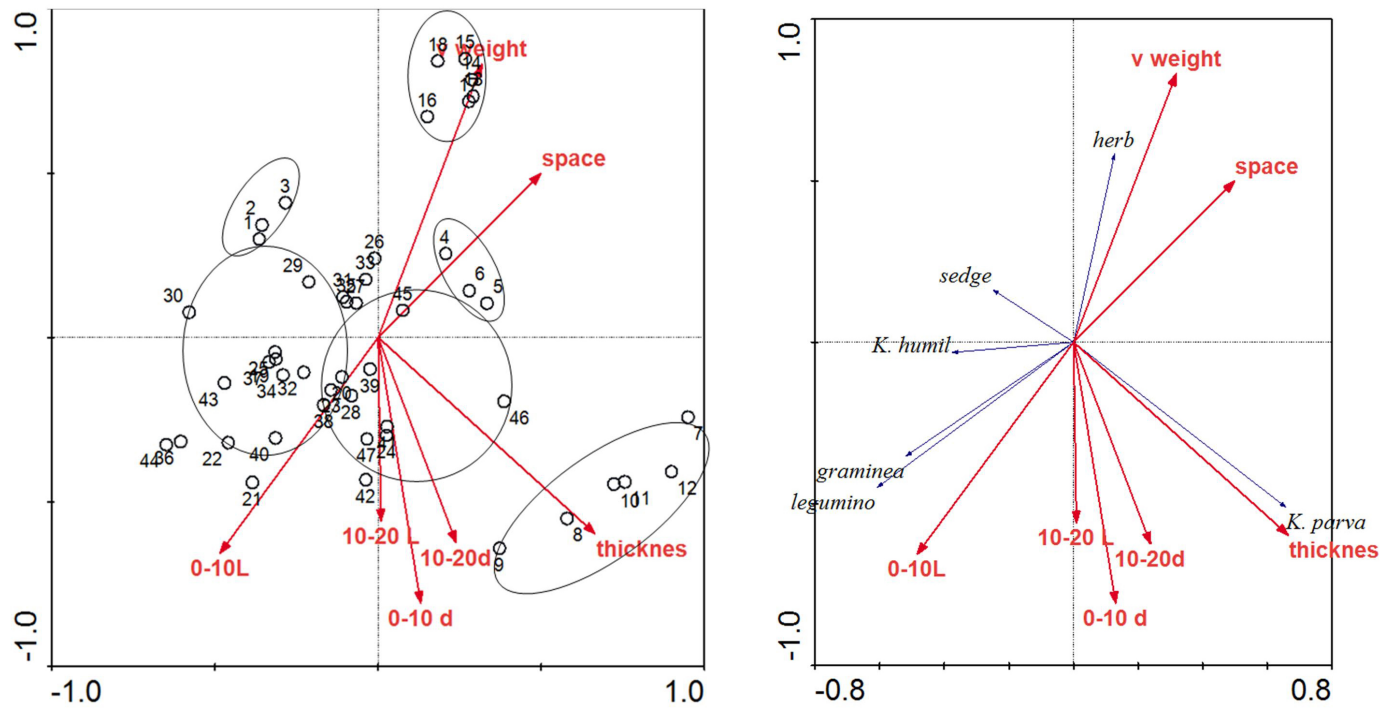

Figure 8. The plant functional groups and environment PCA ordination bioplot. Black items denote plant functional groups, red items denote environmental factors. "V weight" denotes the soil bulk density, "space" denotes the space in community (bared place), "thickness" denotes the thickness of mattic epipedon, $0-10 \mathrm{~L}$ denotes the live roots in the $0-10 \mathrm{~cm}$ soil layer, $10-20 \mathrm{~L}$ denotes the live roots in the $10-20 \mathrm{~cm}$ soil layer, $0-10 \mathrm{~d}$ denotes the dead roots in the $0-10 \mathrm{~cm}$ soil layer, $10-20 \mathrm{~d}$ denotes the dead roots the $10-20 \mathrm{~cm}$ soil layer, herb denotes the non-leguminous broad-leaved herb plant functional group, sedge denotes the sedge plant functional group (excluding $K$. humilis and $K$. pygmaea), Gramineae denotes the Gramineae plant functional group, legumino denotes the Leguminosae plant functional group, K. humil denotes the K. humilis, and L. parva denotes the K. pygmaea.

crease and form a developed cushion to alleviate livestock trampling (Lin et al., 2008), with K. pygmaea being a major contributor. Therefore, the thickness of the mattic epipedon represents a critical environmental index for describing the extent of grassland degradation. The increasing dominance of $K$. pygmaea in the plant community serves as an early alert for degradation in alpine grasslands.

The thickening of the mattic epipedon represents a reciprocal response between the plant community and associated environmental factors during the succession process. As the mattic epipedon thickens, many environmental factors such as the thickness of mattic epipedon, and soil bulk as soil moisture and temperature have been changed, generating positive feedback to overgrazing that has dual effects on alpine grasslands. Initially, increased root biomass enhances water retention and nutrient uptake in the soil $(\mathrm{Li}$ et al., 2012). To a certain extent, this action improves the quality of alpine grassland soils. However, increased biomass leads to higher ratios of roots to soil due to high root volume (G. X. Wang et al., 2007, Wang et al., 2008). Subsequently, the number of dead roots increased due to altered environmental factors. The decomposition of these dead roots was not enhanced for two reasons. First, thick mattic epipedon obstructs the air diffusion and water infiltration, decreasing microbial activity and decomposition. Second, low temperature also leads to slow decomposition of dead roots. Consequently, root activity decreases and causes an imbalance among soil nutrients. At this point, the degradation of alpine meadows is inevitable (Cao et al., 2007).

Therefore, alpine meadow degradation involves two processes. The first process is passive and is driven by overgrazing (Lin et al., 2008; Wang et al., 2008). The second process is active and initiated when the mattic epipedon thickens due to the increasing dominance of K. pygmaea in the plant community and ends as forbs-black-soil beach. In the first stage of succession, alpine grasslands may be rapidly recovered by excluding livestock. However, it is difficult to recover alpine grasslands by excluding livestock once the fourth stage of the succession process has been reached. At this point, it would be necessary to use artificial approaches to restore the degradation grasslands.

However, the mechanisms causing grassland degradation need to be elucidated to fully understand the factors that contribute to this process. Future studies should integrate new tools, such as molecular and isotope approaches, to clarify these mechanisms.

\section{Conclusions}

1. PFG numerical features and root activity, together with certain physical properties of soil, could be used as indicators of the degree of degradation in alpine grasslands. The visible properties such as PFGs and the thickness of mattic epipedon were correlated with invisible properties such as root activities. Therefore, the degree of 
degradation of alpine grasslands can be predicted by development of mattic epipedon and changes in PFGs.

2. Alpine grasslands are very fragile to grazing and are easily degraded. Based on our study above, the degree of degradation in alpine grasslands can be well predicted using relatively few environmental factors. This approach can save time and easily help pastoralists to efficiently manage their grasslands.

Acknowledgements. This work was supported by the Strategic Priority Research Program Climate Change (grant no. XDA05050404), the National Natural Science Foundation of China (grant no. 41030105 and 31270576 and 31500368), and Science and Technology Department of Qinghai Province (grant no. 2013-N-540).

Edited by: A. Cerdà

\section{References}

Ali, K., Kraines, S., Hoang, L., and Yarime, M.: Advancing quantification methods of sustainability: a critical examination emergy, exergy, ecological footprint, and ecological information-based approaches, Ecol. Indic., 37, 81-89, 2014.

Angassa, A.: Effects of grazing intensity and bush encroachment on herbaceous on species and rangeland condition in southern Ethiopia, Land Degrad. Dev., 25, 438-451, doi:10.1002/ldr.2160, 2014.

Araújo, A. S. F., Eisenhauer, N., Nunes, L. A. P. L., Leite, L. F. C., and Cesarz, S.: Soil surface-active fauna in degraded and restored lands of northeast brazil, Land Degrad. Dev., 26, 1-8, 2014.

Bardgett, R.: Causes and consequences of biological diversity in soil, Zoology, 105, 367-374, 2002.

Brandt, J. S., Haynes, M. A., Kuemmerle, T., Waller, D. M., and Radeloff, V. C.: Regime shift on the roof of the world: Alpine meadows converting to shrublands in the southern Himalayas, Biol. Conserv., 158, 116-127, 2013.

Brevik, E. C., Cerdà, A., Mataix-Solera, J., Pereg, L., Quinton, J. N., Six, J., and Van Oost, K.: The interdisciplinary nature of SOIL, SOIL, 1, 117-129, doi:10.5194/soil-1-117-2015, 2015.

Bochet, E.: The fate of seeds in the soil: a review of the influence of overland flow on seed removal and its consequences for the vegetation of arid and semiarid patchy ecosystems, SOIL, 1, 131-146, doi:10.5194/soil-1-131-2015, 2015.

Cao, G. M., Du, Y. G., Wang, Q. L., Wang, C. T., and Liang, D. Y.: Character of passive active degradation process and its mechanism in Alpine Kobresia meadow, J. Mt. Sci., 25, 641-648, 2007.

Cerdà, A.: The effect of season and parent material on water erosion on highly eroded soils in eastern Spain, J. Arid Environ., 52, 319337, 2002

Cerdà, A. and Lavee, H.: The effect of grazing on soil and water losses under arid and Mediterranean climates implications for desertification, Pirineos, 153-154, 159-174, 1999.
Chinese Ecosystem Research Network Scientific Committee: Protocols Standard Biological Observation and Measurement in Terrestrial Ecosystems, China Environmental Science Press, Beijing China, 233-250, 2007.

Christopher, G. M., Danson, F. M., Armitage, R. P., Giraudoux, P., Pleydell, D. R. J., Wang, Q., Qui, J. M., and Craig, P. S.: A random forest approach for predicting the presence of Echinococcus multilocularis intermediate host Ochotona spp. presence in relation to landscape characteristics in western China, Appl. Geogr., 55, 176-183, 2014.

Dai, Z., Meng, J., Muhammad, N., Liu, X., Wang, H., He, Y., Brooks, P. C., and Xu, J.: The potential feasibility for soil improvement, based on the properties of biochars pyrolyzed from different feed stocks, J. Soils Sediments, 13, 989-1000, 2013.

de la Paix, M. J., Lanhai, L., Xi, C., Ahmed, S., and Varenyam, A.: Soil degradation and altered flood risk as a consequence of deforestation, Land Degrad. Dev., 24, 478-485, 2013.

Du, Y. G., Liang, D. Y., Cao, G. M., Wang, Q. L., and Wang, C. T.: Effect on incrassation of mattic epipedon and pasture nutrientmoisture using by grazing in alpine Kobresia meadow, Acta Prata. Sin., 17, 146-150, 2007.

Foggin, J. M.: Depopulating the Tibetan grasslands: national policies and perspectives for the future of Tibetan herders in Qinghai Province, China, Mt. Res. Dev., 28, 26-31, 2008.

Gabarrón-Galeote, M. A., Martínez-Murillo, J. F., Quesada, M. A., and Ruiz-Sinoga, J. D.: Seasonal changes in the soil hydrological and erosive response depending on aspect, vegetation type and soil water repellency in different Mediterranean microenvironments, Solid Earth, 4, 497-509, doi:10.5194/se-4-497-2013, 2013.

Giangiacomo, B.: The human sustainable development index: new calculations and a first critical analysis, Ecol. Indic., 37, 145150,2014

Groen, A. H. and Woods, S. W.: Effectiveness of aerial seeding and straw mulch for reducing post-wildfire erosion, north-western Montana, USA, Int. J. Wildland Fire, 17, 559-571, 2008.

Han, J. G., Zhang, Y. J., Wang, C. J., Bai, W. M., Wang, Y. R., Han, G. D., and Li, L. H.: Rangeland degradation and restoration management in China, Rangeland J., 30, 233-239, 2008.

Harmsen, R., Grogan, P., Tundra, Jorgensen, S. E., and Brian, F. Encyclopedia of Ecology, Elsevier Science, Queen's University, Kingston, ON, Canada, 3633-3639, 2008.

Harris, R. B.: Rangeland degradation on the Qinghai-Tibetan plateau: a review of the evidence of its magnitude and causes, J. Arid Environ., 74, 1-12, 2010.

He, Y. L., Zhou, H. K., Zhao, X. Q., Lai, D. Z., and Zhao, J. Z.: Alpine grassland degradation and its restoration on QinghaiTibet Plateau, Pratacult. Sci., 11, 1-9, 2008

Keesstra, S. D., Temme, A. J. A. M., Schoorl, J. M., and Visser, S. M.: A new, simple model for temporal and spatial sediment fluxes in meso-scale catchments: LAPSUS-D: the hydrological functioning, Geomorphology, 212, 97-107, 2014.

Li, J., Du, Y. G., Zhang, F. W., Guo, X. W., Han, D. R., Liu, S. L., and Cao, G. M.: Mattic epipeon impact on water conservation in alpine meadow, Acta Agr. Sin., 20, 836-841, 2012.

Li, X. L., Perry, G. L. W., Brierley, G., Sun, H. Q., Li, C. H., and Lu, G. X.: Quantitative assessment of degradation classifications for degraded alpine meadows (heitutan), Sanjiangyuan, western 
China, Land Degrad. Dev., 25, 417-427, doi:10.1002/ldr.2154, 2014.

Lin, H. L., Hou, F. J., and Li, F.: Response of underground biomass to grazing trampling in Steppe grassland of Huanxian County, Gansu Province, Northwestern China, Acta Agr. Sin., 16, 186190, 2008.

Lin, J. Y., Lin, T., and Cui, S. H.: Quantitative selection model of ecological indicators and its solving method, Ecol. Indic., 13, 294-302, 2012.

Lin, L., Cao, G. M., Li, Y. K., Zhang, F. W., Guo, X. W., and Han, D. R.: Effects of human activities on organic carbon storage in the Kobresia humilis meadow ecosystem on the Tibetan Plateau, Acta Ecol. Sin., 30, 4012-4018, 2010.

Lin, L., Li, Y. K., Zhang, F. W., Han, D. R., Li, J., and Cao, G. M.: Principal component analysis on alpine Kobresia humilis meadow degradation succession in Qinghai-Tibetan plateau, Chin. J. Grassland, 34, 24-30, 2012.

Lin, L., Li, Y. K., Zhang, F. W., Guo, X. W., and Cao, G. M.: Study on carbon storage administration in Alpine Kobresia humilis meadow related to human activity influence, Acta Prat. Sin., 22, 308-314, 2013a.

Lin, L., Li, Y. K., Zhang, F. W., Du, Y. G., Guo, X. W., Li, J., Liu, S. L., and Cao, G. M.: Soil nitrogen and phosphorus stoichiometry in a degradation series of Kobresia humilis meadows in the Tibetan Plateau, Acta Ecol. Sin., 33, 5245-5251, $2013 \mathrm{~b}$.

Liu, J. Y., Xu, X. L., and Shao, Q. Q.: Grassland degradation in the "Three-River Headwaters" region, Qinghai Province, J. Geogr. Sci., 18, 259-273, 2008.

Lu, Y., Long, R. J., and Lin, L.: Seasonal characteristic of biomass of Polygonum viviparum steppe meadow in Tianzhu Alpine region, Grassland Turf, 1, 1-4, 2007.

Mekuria, W. and Aynekulu, E.: Exclosure and land management for restoration of the soils in degraded communal grazing lands in Northern Ethiopia, Land Degrad. Dev., 24, 528-538, 2013.

Nanko, K., Giambelluca, T. W., Sutherland, R. A., Mudd, R. G., Nullet, M. A., and Ziegler, A. D.: Erosion Potential under Miconia calvescens Stands on the Island of Hawaii, Land Degrad. Dev., 26, 218-226, 2015.

Pereg, L. and McMillan, M.: Scoping the potential uses of beneficial microorganisms for increasing productivity in cotton cropping systems, Soil Biol. Biochem., 80, 349-358, 2015.

Puente, M. E., Bashan, Y., Li, C. Y., and Lebsky, V. K.: Microbial populations and activities in the rhizoplane of rock-weathering desert plants. I. Root colonization and weathering of igneous rock, Plant Biol., 6, 629-642, 2004.

Shang, Z., Cao, J., Guo, R., Henkin, Z., Ding, L., Long, R., and Deng, B.: Effect of enclosure on soil carbon, nitrogen and phosphorus of alpine desert rangeland, Land Degrad. Dev., doi:10.1002/ldr.2283, online first, 2014.

Sun, D. S.: Studies on the Effects of Grazing Intensity on Vegetation and Soil in Alpine Meadow on the Eastern Qinghai-Tibetan Plateau, Lanzhou University, Lanzhou, China, 2012.

Sun, H. L. and Zheng, D.: Formation and Evolution and Development of the Tibetan Plateau, Guangdong Science and Technology Press, Guangdong, China, 1-10, 1998.
Wang, C., Wang, G., Wang, Y., Rashad, R., Ma, L., Hu, L., and Luo, Y.: Fire alters vegetation and soil microbial community in alpine meadow, Land Degrad. Dev., doi:10.1002/ldr.2367, online first, 2015.

Wang, C. T., Wang, Q. L., Jing, Z. C., Feng, B. F., Du, Y. G., Long, R. J., and Cao, G. M.: Vegetation roots and soil physical and chemical characteristic changes in Kobresia pygmaea meadow under different grazing gradients, Acta Prat. Sin., 17, 9-15, 2008.

Wang, G. X., Wang, Y. B., Li, Y. S., and Cheng, H. Y.: Influences of alpine ecosystem responses to climatic change on soil properties on the Qinghai-Tibet Plateau, China, Catena, 70, 506-514, 2007.

Wang, J. B., Liu, J. Y., and Shao, Q. Q.: Spatial-temporal patterns of net primary productivity for 1988-2004 based on GloPemCevsa model in the "three-river headwaters" region of Qinghai Province, J. Plant Ecol.-CH, 33, 254-269, 2009.

Wang, Q. J., Jing, Z. C., and Wang, W. Y.: The study of grassland and resource, ecological environment and sustainable development in Qinghai-Xizang Plateau, Qinghai Prat., 6, 1-11, 1997.

Wang, Q. J., Wang, W. Y., and Deng, Z. F.: The dynamics of biomass and the allocation of energy in alpine Kobresia meadow communities, Haibei region of Qinghai Province, Acta Phytoecol. Sin., 22, 222-230, 1998.

Wang, Q. L., Cao, G. M., and Wang, C. T.: The impact of grazing on the activities of soil enzymes and soil environmental factors in alpine Kobresia pygmaea meadow, Acta Meta. Sin., 13, 856864, 2007.

Wen, L., Dong, S. K., Zhu, L., Li, X. Y., Shi, J. J., Wang, Y. L., and Ma, Y. S.: The construction of grassland degradation index for Alpine meadow in Qinghai-Tibetan Plateau, Proc. Environ. Sci., 2, 1966-1969, 2010.

Yang, R. R.: Analysis on western China grassland degradation and of sustainable development, Pratacult. Sci., 19, 23-27, 2002.

You, Q. G., Xue, X., Peng, F., Xu, M. H., Duan, H. C., and Dong, S. Y.: Comparison of ecosystem characteristics between degraded and intact alpine meadow in the Qinghai-Tibetan Plateau, China, Ecol. Eng., 71, 133-143, 2014.

Zhang, J. X., Cao, G. M., Zhou, D. W., Hu, Q. W., and Zhao, X.: The carbon storage and carbon cycle among the atmosphere, soil, vegetation and animal in the Kobresia humilis alpine meadow ecosystem, Acta Ecol. Sin., 23, 627-634, 2003.

Zhang, Y. M., Zhang, Z. B., and Liu, J. K.: Burrowing rodents as ecosystem engineers: the ecology and management of plateau zokors Myospalax fontanierii in alpine meadow ecosystems on the Tibetan Plateau, Mammal Rev., 33, 284-294, 2003.

Zhao, G., Mu, X., Wen, Z., Wang, F., and Gao, P.: Soil erosion, conservation, and eco-environment changes in the Loess Plateau of China, Land Degrad. Dev., 24, 499-510, 2013.

Ziadat, F. M. and Taimeh, A. Y.: Effect of rainfall intensity, slope and land use and antecedent soil moisture on soil erosion in an arid environment, Land Degrad. Dev., 24, 582-590, 2013. 